\title{
Effect of Heat-Moisture Treatment on the Digestibility and Viscous Characteristics of Hard Wheat Flour and Separated Wheat Starch
}

\author{
Ikeda Masayo*, Matsumori Shingo*† and Akuzawa Sayuri* ${ }^{*}$ \\ * Tokyo University of Agriculture, Faculty of Applied Bio-science, Department of Nutritional Science, \\ 1-1-1, Sakuragaoka, Setagayaku, Tokyo 156-8502
}

\begin{abstract}
The effects of heat-moisture treatment on the digestibility and viscous characteristics of hard wheat flour and separated wheat starch were examined to obtain basic data and information on texture modifier materials in food. From SEM, starch granules of heat-moisture-treated wheat flour appeared to change so as to have a flattened shape and showed adherence to other starch granules. The protein content and moisture content were not changed by heat-moisture treatment. The rate of protein degradation by pronase and the solubility of flour proteins in $0.5 \mathrm{M}$ sodium chloride and water were markedly lower for the heat-moisture-treated wheat flour than for untreated native flour. The heat-moisture-treated wheat flour and separated wheat starch showed distinct peak viscosities; in particular, native and heat-moisture-treated starch showed considerable differences in their pasting temperature and peak viscosity. The apparent activation energy of native wheat flour paste at $14.7 \mathrm{~kJ}$ $/$ mol was greater than that of the heat-moisture-treated wheat flour paste at $13.4 \mathrm{~kJ} / \mathrm{mol}$. In terms of starch pastes, the apparent activation energy of the heat-moisture-treated starch sample was $10.5 \mathrm{~kJ} /$ mol, whereas that of the native sample was $25.9 \mathrm{~kJ} / \mathrm{mol}$.
\end{abstract}

(Received Jan. 9, 2008; Accepted Mar. 18, 2008)

Key words : Heat-moisture treatment, Wheat flour, SEM, Viscous characteristic, Apparent activation energy 湿熱処理, 小麦粉, 走査型顕微鏡, 粘度特性, 活性化エネルギー

The texture and rheology of food are very important and influential factors in the evaluation of foods. Food processing companies have been varying mixture proportions and improving processing techniques in response to the demand for food with new textures.

Heat-moisture treatment is a hydrothermal treatment that modifies the physicochemical properties of starch, but does not destroy the granular structure of starch. Many researchers have reported on the physicochemical properties of heat-moisture-treated $\operatorname{starch}^{1) \sim 10)}$ and on the rheological properties of starch pastes $^{11) \sim 15)}$. In a previous study ${ }^{14)}$, we reported that a heat-moisture-treated corn starch gel, which produces a soft-food feeling in the mouth, was suitable for use as a new food material. The physical modification of starch, as a natural material with high safety, is of interest in food applications. There have been few reports on the properties of heat-moisture-treated tuber, $\operatorname{root}^{16)}$, bean ${ }^{17)}$, or wheat flour $^{18)}$; nevertheless, we have been using these materials in cookies, pastry, bread, and breakfast cereals $^{19)}$.

The objective of this study was to assess the effect of heat-moisture treatment on the viscous characteristics of wheat flour and separated wheat starch by comparing native and heat-moisturetreated wheat flour and separated wheat starch to obtain basic data on these useful food materials. We compared the starch granule shape, protein digestibility by pronase, and viscous characteristics of heat-moisture-treated wheat flour and separated wheat starch.

\section{Materials and Methods}

\section{Materials}

Two hard wheat flour samples (Ohtion produced by Nishin Seifun Co., Ltd.), one native and the

$\S$ Corresponding author, E-mail:akuzawa@nodai.ac.jp

$\dagger$ Present address : Komazawa Woman's Junior College, Department Food and Nutrition; 238, Hamasaka, Inagi-shi, Tokyo $206-8511$ 
other treated with heat moisture at $125^{\circ} \mathrm{C}$ for $20 \mathrm{~min}$ by Sanwa Cornstarch Co., Ltd., were used. The starch was separated from each wheat flour sample with $0.5 \%$ aqueous $\mathrm{NaOH}$, and then washed and centrifuged with distilled water until a $\mathrm{pH}$ of 7 was obtained for the separated wheat starch-water slurry. After purification, the starch samples were centrifuged and dried in a dry-air oven overnight at $40^{\circ} \mathrm{C}$.

\section{Microscopic observation}

Samples were coated with platinum (about $20 \mathrm{~nm}$ thick) by magnetron sputtering (JEOL JUC-5000), for 6 7 min and examined with a Hitachi HFS-2 scanning electron microscope at an accelerating voltage of 0.8 $\mathrm{kV}$.

\section{Chemical analysis}

The water activity was determined using a Testo 650 instrument (Shimadzu Co., Ltd.). A wheat flour sample of $10 \mathrm{~g}$ was put into the Testo 650 chamber, and measurements were taken in a constanttemperature oven at $25^{\circ} \mathrm{C}$. The protein content was determined by the Kjeldahl method $(\mathrm{N} \times 5.7)$. The enzymatic digestibility of each wheat flour sample was carried out by adding 40,000 PU of pronase (Merck Co., Ltd. 4, 000, $000 \mathrm{PU} / \mathrm{g}$ EC 3.4.24.4) to a starch slurry of $100 \mathrm{~m} \ell$ containing $1 \mathrm{~g}(\mathrm{w} / \mathrm{w}$ on the basis of the anhydride) of wheat flour. Aliquots of $5 \mathrm{~m} \ell$ were removed at specified time intervals, pipetted into $5 \mathrm{~m} \ell$ of $10 \%$ trichloroacetic acid (TCA) and centrifuged. Aliquots of the supernatant were analyzed for soluble proteins as TCA-soluble digestion products by the Lowry method ${ }^{20)}$.

\section{Pasting properties}

The gelatinization and pasting properties were determined with a Rapid Visco Analyzer (RVA; Newport Scientific Pty., Ltd.). Samples of $2.5 \mathrm{~g}$ of wheat flour or starch $(10 \% \mathrm{w} / \mathrm{w}$ on the basis of the anhydride) were each transferred into a canister and approximately $25 \mathrm{~m} \boldsymbol{\ell}$ of distilled water was added (corrected to compensate for $10 \%$ concentration). The slurry was heated from 30 to $95^{\circ} \mathrm{C}$ at $1.5^{\circ} \mathrm{C} / \mathrm{min}$, held at $95^{\circ} \mathrm{C}$ for $20 \mathrm{~min}$, and finally cooled to $30^{\circ} \mathrm{C}$ at $1.5^{\circ} \mathrm{C} / \mathrm{min}$. The gelatinization and pasting properties were calculated from the obtained pasting curves showing the apparent viscosity in units of cp. RVU was calculated by multiplying what by the coefficient of $8.33 \times 10^{-2}$.

\section{Viscous characteristics of wheat flour and separated starch pastes}

Wheat flour and separated starch pastes for measurement of apparent viscosity were prepared as follows. Six percent ( $\mathrm{w} / \mathrm{w}$ on the basis of the anhydride) suspensions of wheat flour and separated starch were allowed to swell for $15 \mathrm{~min}$, after which they were heated for $20 \mathrm{~min}$ in an autoclave (ES-215, Tomy Co., Ltd.) at $105^{\circ} \mathrm{C}$. Each wheat flour sample and separated starch paste sample was allowed to stand at $20^{\circ} \mathrm{C}$ for $30 \mathrm{~min}$ before shear-thinning behavior was measured by a Rotovisco CV-20 instrument (Hakke Co., Ltd.) with an ME-30 sensor consisting of a coaxial cylinder and beaker. The measurement conditions were applied at each temperature of 10 , $20,30,40$ and $50^{\circ} \mathrm{C}$ at a fixed shear stress of $50\left(\mathrm{~s}^{-1}\right)$. The point at which the rate of change of stress was under $1 \%$ was selected as the apparent viscosity at a specific shear rate. The effect of temperature on apparent viscosity can be described by the Andrade relationship as the apparent activation energy as follows :

$$
\eta=\mathrm{Ae}^{(\mathrm{Ea} / \mathrm{RT})}
$$

where $\eta$ is the apparent viscosity, Ae is a constant, $\mathrm{Ea}$ is the apparent activation energy $(\mathrm{J} / \mathrm{mol}), \mathrm{T}$ is the absolute temperature $(\mathrm{K})$ and $\mathrm{R}$ is the gas constant $(\mathrm{J} / \mathrm{mol} \mathrm{K})$.

\section{RESULTS and DISCUSSION}

\section{Microscopic observation}

Fig. 1 shows scanning electron microscope (SEM) of the surfaces of wheat flour and separated starch samples. The native wheat flour has two types of granule with the shape of a swollen ellipse and a smooth surface, the diameters of the two types of granule being about $5 \sim 7 \mu \mathrm{m}$ and $15 \sim 30 \mu \mathrm{m}$. In the case of heat-moisture-treated wheat flour, however,
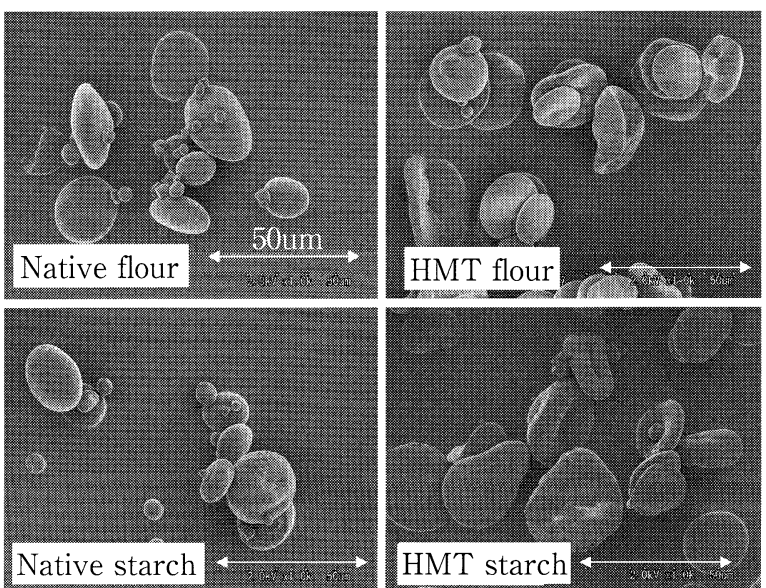

Fig. 1 Scanning Electron Micrographs (SEM) Of wheat flour and separated wheat starch samples 
the surface of the granules shows cracks and the elliptical shapes are distorted. In addition, the starch granules of heat-moisture-treated wheat flour are flattened and contain a hollow portion at the center, and seem to adhere to several other starch granules. This deviation from the native spherical shape seems to have been caused by the effects of the heat-moisture treatment. These observations thus suggest that the internal structure of the starch granules and the formation of proteins have disintegrated ${ }^{5)}$.

\section{Chemical analysis of wheat flour samples}

The water content, water activity, protein content, and degradation rate of the protein of the native and heat-moisture-treated wheat flour samples are shown in Table 1 . The moisture and protein content of the wheat flours were not changed by heatmoisture treatment; thus, this treatment seems to have changed the structure of the components without changing their content.

The degradation rate of protein in the native and the heat-moisture-treated wheat flour samples increased with time. The degradation rate of the native sample was about $30 \%$ after 5 minutes and almost reached a plateau after 30 minutes. In contrast, the degradation rate of the heat-moisturetreated flour was $2.3 \%$ after 5 minutes, and this rate increased only slightly after 30 minutes. However, these values were considerably lower than the native ones. HANSEN et $a l^{21)}$ have reported that albumins, globulins, and some gliadins aggregate, forming large urea-insoluble complexes as indicated by a decrease in protein solubility in urea. The content of salt-soluble protein was decreased from about $50.9 \%$ to $13.8 \%$ by heat-moisture treatment (data not shown). The degradation rate of flour protein by pronase was decreased by heat-moisture treatment. This observation suggests that the number of sites for degradation of wheat protein decreased because of aggregation resulting from the treatment. This aggregation was apparent from the combination of protein and starch granules that is shown in the SEM, and the degradation rate seems to have been decreased by these changes.

\section{3 . Change in viscosity with temperature during gelatinization of wheat flour samples}

The shape of the pasting curve differed for the native and heat-moisture-treated samples, as showed in Fig. 2. Significant differences were observed, between native and heat-moisture-treated wheat flour or separated starch, during both heating and cooling in an excess of water. The pasting temperature of separated starch was increased by about $20.8^{\circ} \mathrm{C}$ by heat-moisture treatment. The heat-moisture-treated wheat flour and separated starch showed distinct peak viscosities; in particular, the native and heatmoisture-treated starch samples differed in their pasting temperature and peak viscosity. However, the trough viscosity and final viscosity values were similar for the native and heat-moisture-treated flour. These results could indicate that heat-moisture treatment led only to the formation of wheat flour granules covered with aggregated protein ; thus, there were few differences in RVA properties between heat-moisture-treated wheat flour and native flour. In contrast, we previously reported ${ }^{13) \sim 15)}$ that viscosity properties change markedly with this treatment, although the difference between the trough viscosity and final viscosity of each separated starch was

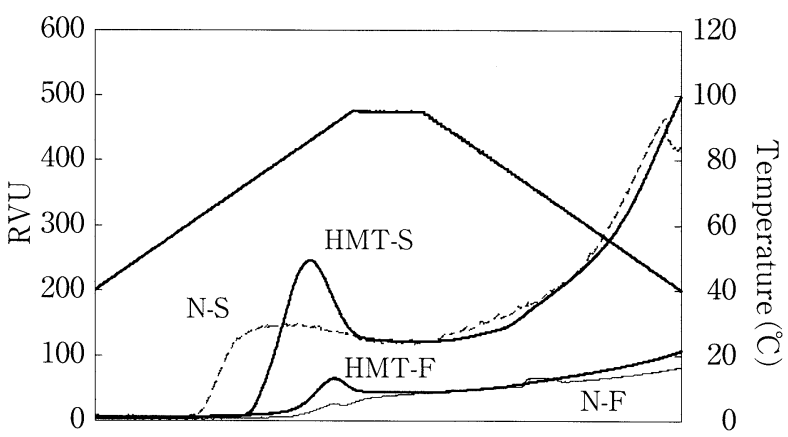

Fig. 2 RVA pasting curves of $10 \%$ wheat flour and separated wheat starch samples

N-S ; native starch, HMT-S ; heat-moisture-treated starch

$\mathrm{N}-\mathrm{F}$; native wheat flour,

HMT-F ; heat-moisture-treated wheat flour

Table 1 Moisture content, water activiy, protein content, and protein digestibility by pronase of the native and heat-moisture-treated wheat flours

\begin{tabular}{lccccccc}
\hline \multirow{2}{*}{ Sample } & \multirow{2}{*}{$\begin{array}{c}\text { Moisture } \\
\text { content }(\%)\end{array}$} & Water activity & \multirow{2}{*}{$\begin{array}{c}\text { Protein } \\
\text { content }(\%)\end{array}$} & \multicolumn{4}{c}{ Protein Digestibility (\%) } \\
\cline { 5 - 8 } Native & 11.45 & 0.538 & 14.12 & 31.4 & 39.0 & 50.0 & 54.6 \\
HMT & 11.47 & 0.615 & 14.11 & 2.3 & 12.0 & 33.1 & 44.5 \\
\hline
\end{tabular}


negligible. We speculate that the separated starch of this heat-moisture-treated wheat flour was not modified significantly by the treatment, because the effect of heat-moisture treatment was reduced by the existence of protein.

\section{Temperature dependence of the apparent viscosity of each wheat flour and separated starch paste}

The change in quality, particularly, the viscosity of fluid foods, is very important during the processing and storage of food products. The effect of temperature on the apparent viscosity at a specified shear rate of the power law model of a fluid often can be described by the Andrade relationship. The apparent viscosity versus temperature plots for both wheat flour and separated starch pastes are shown in Fig. 3. From a plot of $\ln \eta_{\mathrm{a}}$ versus $(1 / \mathrm{T})$, the apparent activation energy of each $6 \%$ wheat flour and separated
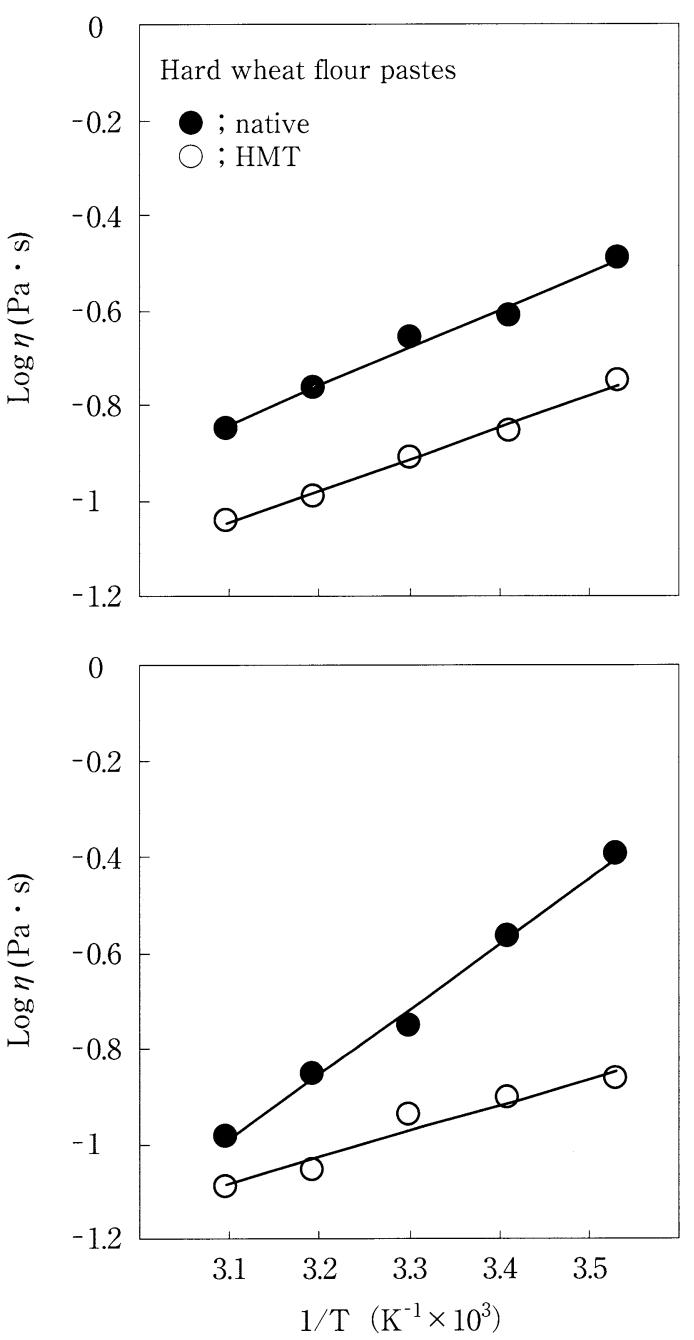

Fig. 3 The change in the apparent viscosity versus $1 / \mathrm{T}$ for $6 \%$ wheat flour and separated wheat starch pastes
Table 2 Apparent activation energy of $6 \%$ wheat flour and separated wheat starch pastes

\begin{tabular}{lcc}
\hline Sample & \multicolumn{2}{c}{$\begin{array}{c}\text { Apparent } \\
\text { energy }\end{array}$} \\
& \multicolumn{1}{c}{$\begin{array}{l}(\mathrm{kJ} / \mathrm{mol}) \\
\text { Flour }\end{array}$} & Starch \\
Native & $14.7 \pm 0.7$ & $25.9 \pm 0.1$ \\
HMT & $13.4 \pm 1.0$ & $10.5 \pm 1.7$ \\
\hline
\end{tabular}

starch paste was calculated in the temperature range of $10 \sim 50^{\circ} \mathrm{C}$ by using the Andrade equation, and the resultant values are shown in Table 2.

The apparent activation energy of the native wheat flour paste was $14.7 \mathrm{~kJ} / \mathrm{mol}$, and that of the heat-moisture-treated one was $13.4 \mathrm{~kJ} / \mathrm{mol}$. The apparent activation energy of the heat-moisturetreated wheat flour was slightly lower than that of the native one, but the difference was not significant. In the case of the separated starch pastes, the apparent activation energy of the heat-moisture-treated starch paste was $10.5 \mathrm{~kJ} / \mathrm{mol}$, and that of the native one was $25.9 \mathrm{~kJ} / \mathrm{mol}$. From these results, we can infer that the RVA viscosity behaviors are not relation to the apparent viscosity, and the influence of temperature on viscosity was reflected in the apparent viscosity over the range of temperature. The apparent activation energy is indicative of thermal stability because the viscosity change that occurs at the temperature of the paste was converted into energy. Heat-moisture treatment is a more useful modification method of controlling the viscous properties of starches than wheat flours. We propose that replacing the amount and type of wheat cereal with starch would be a good way to obtain new textures of foods; for example, replacing part of the wheat flour with heat-moisture-treated wheat starch would result in a change in the apparent viscosity and thermal stability in a mixture of foods.

\section{References}

1) Donovan, J. W., Lorenz, K. and Kulp, K. : Differential scanning calorimetry of heat-moisture treated wheat and potato starches, Cereal Chemistry, 60, 381 387 (1983)

2 ) Franco, C. M. L., Ciacco, C. F. and Tavares, D. Q. : Effect of heat-moisture treatment on the enzymatic susceptibility of corn starch granules, Starch, 47, 223〜228 (1995).

3 ) Hagiwara, S., Esaki, K., Kitamura, S. and Kuge, T.: Observation by photo microscopic and X-ray diffraction method of heat-moisture treatment on 
starch granules, Denpun Kagaku, 38, $241 \sim 247$ (1991)

4) Hoover, R. and Manuel, H.: The effect of heatmoisture treatment on the structure and physicochemical properties of normal maize, waxy maize, dull waxy maize and amylomaize $\mathrm{v}$ starches, Jounal of Cereal Science, 23, 153 162 (1996)

5 ) Kawabata, A. , Takase, N. , Miyoshi, E. , Sawayama, S. Kimura, T. and Kudo, K. : Microscopic obsevation and X-ray diffractometry of heat-moisture treated starch granules, Starch, 46, 463 469 (1994)

6 ) Hoover, R. and Vasanthan, T. : Effect of heatmoisture treatment on the structure and physicochemical properties of cereal, legume, and tuber starches, Carbohydrate Research. 252, 33 53 (1994)

7 ) SAIR, L. : Heat-moisture treatment of starch, Cereal Chemistry, 44, 8 26 (1967)

8 ) Lorenz, K. and Kulp, K.: Physical properties of defatted and heat-moisture treated starches, Starch, 35, 123 129 (1983)

9 ) Gunaratne, A. and Hoover, R. : Effect of heatmoisture treatment on the structure and physicochemical properties of tuber and root starches, Carbohydrate Polymers, $49, \quad 425 \sim 437$ (2002)

10) SAng, Y. and SeIB, P. A. : Resistant starches from amylose mutants of corn by simultaneous heat-moisture treatment and phosphorylation, Carbohydrate Polymers, 63, 167 175 (2006)

11) Abraham, T. E.: Stabilization of paste viscosity of cassava starch by heat-moisture treatment, Starch, 45, 131 135 (1993)

12) Collado, L. S., Mabesa, L. B., Oates, C. G. and CORKe, H.: Bihon type noodles from heat-moisture treated sweet potato starch, Jounal of Food Science, 66, 604 609 (2001)

13) Kawabata, A., Akuzawa, S., Yazaki, T. and OtuBo, Y.: Sol-Gel transition and elasticity of heat -moisture treated starches, Journal of Applied Glycoscience, 43, 479 485 (1996)

14) Kawabata, A., Takase, N., Akuzawa, S. and Sawayama, S. : Gelatinization characteristics of heat-moisture treated potato and corn starches, Journal of Applied Glycoscience, 43, $471 \sim 477$ (1996)

15) Aikawa, R., Akuzawa, S., Sawayama, S. and Kawabata, A.: Gelatinization properties of heat- moisture treated Katakuri starch and its elasticity at near the sol-gel transition, Journal of Applied Glycoscience, 46, 151 157 (1999)

16) Abraham, T. E., Raja, K. C. M., Manoharan, E. P. and MATHEW, A. G. : Effect of heat-moisture treatment on textural characteristics of cassava flour, Cereal Chemistry, 60, $7 \sim 8$ (1983)

17) Pilosof, A. M. R., Boquet, R. and Bartholomai, G. B. : Effect of heat treatment of field bean (Phaseolus vulgaris) flour and protein isolate on water uptake, Cereal Chemistry, 63, 456 458 (1986)

18) Vadlamani, K. R. and Seib, P. A. : Reduced browning in raw oriental noodles by heat and moisture treatment of wheat, Cereal Chemistry, 73, 88 95 (1996)

19 ) Hoseney, R. C. and Rogers, D. E. : The formation and properties of wheat flour doughs, Critical reviews in Food Science and Nutrition, 29, 73 $\sim 93(1990)$

20) Lowry, O. H., Rosebrough, N. J., FArr, A. L. and Randall, R. J.: Protein measurement with the folin phenol reagent, Journal of Biological Chemistry, 193, 265 275 (1951)

21) Hansen, L. P., Johnston, P. H. and Ferrel, R. E. : Heat-moisture effect on wheat flour I. Physicalchemical changes of flour proteins resulting from thermal processing, Cereal Chemistry, 52, 459 472 (1975)

\section{湿熱処理が強力小麦粉のタンパク質の消化性 および粘性特性に及ぼす影響}

\author{
池田昌代* ·松森慎悟*† ・阿久澤さゆり* \\ * 東京農業大学応用生物科学部 \\ （１56-8502＼cjkstart東京都世田谷区桜ヶ丘 1-1-1） \\ $\dagger$ 現在駒沢女子短期大学食物栄養科 \\ （テ206－8511東京都稲城市坂浜238）
}

強力粉に湿熱処理を施し, タンパク質の消化性，粘性 特性を測定した。また, 湿熱処理小麦粉から澱粉を分離 して澱粉糊液の粘性特性について検討し, 食感改良素材 としての基礎的データを収集した。SEM観察では, 湿 熱処理により粒形が扁平になり, 中央部分にくぼみが生 じており，内部構造の変化が示唆された。湿熱処理によ る夕ンパク質含量, 水分含量の変化はなかったが，プロ ナーゼによるタンパク質の消化率および塩可溶性タンパ ク質量は，未処理に比べて著しく低下していた。湿熱処 理小麦粉およびそこから分離した澱粉のRVA曲線は, 粘度立ち上がり温度が上昇し, 最大ピークを示す曲線に 
変化していた。平衡粘度から見かけの活性化エネルギー を算出し，小麦粉および澱粉ペーストの温度安定性を検 討したところ，小麦粉ペーストは有意な差はみられなか
ったが，澱粉ペーストは湿熱処理 $10.5 \mathrm{~kJ} / \mathrm{mol}$ ，未処理 $25.9 \mathrm{~kJ} / \mathrm{mol}$ であり熱安定性が著しく向上していた。

(平成 20 年 1 月 9 日受付，平成 20 年 3 月 18 日受理) 